\title{
Teachers' Covid-19 Awareness, Distance Learning Education Experiences and Perceptions towards Institutional Readiness and Challenges
}

\author{
Lapada Aris Alea \\ Eastern Samar State University, Eastern Samar, Philippines \\ https://orcid.org/0000-0002-5170-1531 \\ Miguel Frosyl Fabrea \\ Ramon Magsaysay High School, Manila, Philippines \\ https://orcid.org/0000-0001-6866-1102 \\ Robledo Dave Arthur Roldan \\ St Jude Catholic School, Manila, Philippines \\ https:// orcid.org/0000-0003-4035-2791 \\ Alam Zeba Farooqi \\ De La Salle University, Manila, Philippines \\ https://orcid.org/0000-0003-1108-576X
}

\begin{abstract}
Amidst the threat of COVID-19 pandemic in the Philippines, the educators, students, and the school are still coping and adjusting to the distance learning education. This study explored teachers' awareness about the COVID-19 pandemic and their opinion on their respective schools' readiness, as well as their response to the challenges of conducting distance learning education in the Philippines. A validated questionnaire was developed to collect the relevant data for this study. The initial reliability test obtained 8.9 Cronbach's alpha. Data gathering procedure was done through Google forms, which, after validation from the respective DepEd divisions and universities, were subsequently sent to the teachers via email. The results show that the teachers were highly aware of the presence and consequences caused by the COVID-19 pandemic. The correlation between teacher's demographic profiles and awareness to COVID-19 shows no relationship at all. Nevertheless, the length of teaching experience and specialization is very strongly correlated to readiness to distance learning education. Simultaneously, the teachers' geographic location is strongly correlated to readiness to adapt to distance learning education. Furthermore, only the teachers' gender has a significant difference in their awareness of the COVID-19 pandemic. In contrast, teachers' gender, length of teaching experience, and geographic location have significant differences with their readiness to distance learning education. This study can be used as a basis for
\end{abstract}


further research particularly in developing institutional plans to better understand the status of their teachers and educational organizations, and schools' readiness to teach and learn through distance learning approach; hence, preserving and continuing educational mission during the current or future pandemic as well as be prepared for any natural disasters.

Keywords: COVID-19 pandemic; teachers' awareness; readiness; distance learning education

\section{Introduction}

The newly identified $\beta$-coronavirus was first named the 2019-novel coronavirus first occurred at Wuhan, China, in December 2019. On February 11, 2020, the 2019novel coronavirus was officially named SARS-CoV-2 by the World Health Organization (WHO), also known as the COVID-19 (Guo et al., 2020). The COVID19 is not just causing health crises around the world, but it is also affecting all spheres of life, including the field of education. Educators resorted to online platforms to reach out to students, webinars became a temporary classroom, parents were called for monitoring at home, and students got deprived of social interaction among peers. The WHO advised educators and students to conduct alternative learning due to the COVID-19 outbreak to mitigate school cancellation of classes through providing a resource list of the World Bank's Edtech teams to provide some online materials that can be used during the pandemic. The program aims to elevate the loss of learning and provide remote learning opportunities while schools are closed. Furthermore, the mandate provides guiding principles and delivery of online classes and approaches to be given by stakeholders like teachers and parents (World Bank, 2020a).

Various countries around the world, Colombia, Italy, Japan, Poland etc., including the Philippines, responded to the call of WHO through their respective Ministry of Education. Various educational platforms were utilized like YouTube, learning management system (LMS), digital library, internet streaming or broadcast, repositories like Open Educational Resources (REA), and the like based on their availability in a particular country. Higher education makes use of Zoom and Google Hangouts, while teachers were encouarged to take advantage of various websites, such as Facebook, WhatsApp, Google forms. EdTech Hub, UNESCO Education Alliance, Learning Keeps Going (U.S. consortium), Inter-Agency Network for Education in Emergencies (INEE ), Commonwealth of Learning, and many others (World Bank, 2020b).

Responding to the call of WHO, the Department of Education (DepEd, Philippines), created a series of DepEd Memorandum (DM) No. 15, 21, 23, 31 and 34 in the first quarter of 2020 entitled "Creation of a Task Force for the Management of Department of Education Response to Novel Coronavirus Acute Respiratory Disease (2019-nCoV ARD)" (Department of Education, 2020a). The DepEd, Philippines, also created a learning website called DepEd Commons catering for Alternative Learning School (ALS) students, Out-of-School-Youth (OSYA), regular learners from Kindergarten to Grade 8. The online learning hub 
is available both for public and private schools all over the country. The website aims to reinforce education anytime and anywhere suitable for learners who have access to the internet using equipment such as smartphones, tablets, laptops, and desktop computers (Department of Education, 2020b).

The Technical Education Skills Development Authority (TESDA), has recorded 19,598 enrollees in technical-vocational courses that use various platforms online in the first three weeks of enforced Luzon-wide lockdown (Esguerra, 2020). As the students studying in the major cities moved to the provinces as persons under monitoring or persons under investigation for at least 14 days, the majority of families and households had to adjust to community quarantine that eventually modified into Enhanced Community Quarantine (ECQ). The ECQ became an opportunity for many people to enroll in various technical-vocational courses online, such as the overseas Filipino workers (OFW) around the world. The latter was also affected by massive lockdown. In the global context of the work stoppage eventually, fast track adoption of digital transformation led to unprecedented changes like work from home and widespread use of online learning applications (Quimba et al. (2018). When the community quarantine started, it was almost the end of the school year among the $\mathrm{K}$ to 12 learners; hence, teachers used the Learners' Information System (LIS) online to finish their classes to submit the last quarter grades of their students. School year and semester had ended within the ECQ, which led the basic education schools and universities to adapt the distance learning education.

The COVID-19 pandemic led educators to online education readiness. According to Phan \& Dang (2017), factors such as training, attitude, technical competence, time constraints, pedagogy, and methodology were among the major distance learning education elements. In a study conducted by Ventayin (2018) on the readiness of DepEd Teachers to online teaching, showed that despite the limited experience in distance education such as technical skills, time management, knowledge and attitude in online education, they were still able to cope with the trends in distance learning. Moreover, readiness and satisfaction levels were also found among prospective teachers in other countries like Turkey and Thailand in terms of web-based education (Ozturk, Ozturk \& Ozen, 2018; and Akarawang, Kidrakran \& Nuangchalerm, 2015). Further, in the study on the response from 205 online faculty of higher institutions in the United States in terms of readiness, attitude and ability to teach online in terms of course design, course communication, time management and technical aspects most of the responses were rated high (Martin, Budhrani \& Wang, 2019).

Furthermore, another study on distance education readiness found $90 \%$ of the total special education and preschool teachers surveyed got motivated to implement distance education despite having diverse students, lack of specialists, home-schooled, under long medical treatment, attending short stay with group or family and private school (Fedina et al., 2017). Likewise, in another study, higher education mentors show a positive attitude and motivation to teach university students special needs like hearing and visually impaired despite the risk and challenges in learning materials, pedagogy, monitoring, implementation and 
psychological understanding (Movkebayeva et al., 2018). As this pandemic is slated to exist until the preventive vaccine is discovered, it is essential to know how the educators who are the prime facilitators of the education adjusted to this transition and what challenges they faced while adapting to this transition as their preparedness for the coming times.

This study aimed to find the factors and determinants that can facilitate a smooth transition to distance learning in the Philippines. It is already being predicted that it will be used as a primary mode of imparting education during the pandemic (Dill, et al., 2020).

\section{Methodology}

The descriptive research design was adapted in realizing this pursuit (Nassaji, 2016). This study assessed teachers' awareness of COVID-19 pandemic, readiness to distance learning education, and the perceived challenges of distance learning education during the ECQ in the Philippines. Data gathering procedure was done through Google forms, which were sent to the respective DepEd divisions and universities and subsequently sent to the teachers via email. The random sampling technique was utilized to gather responses from teachers regardless of their gender, length of teaching experience, location of school (urban or rural), school type (public or private), and level of affiliated institution (Elementary, Secondary, Senior High School and College). A total of 2300 responses were received in two weeks' time from the different schools' divisions and universities in the Philippines.

\subsection{Research Instruments}

The instrument, "Questionnaires on Teachers Awareness, Readiness and Online Learning Experience During COVID-19 ECQ," is a researcher-made questionnaire. This instrument was divided into four parts: (1) collecting information about the demographic profile of respondents, (2) teachers' awareness of COVID-19 tailored from the "Coronavirus Disease 2019 Report" (WHO, 2020), (3) teachers' readiness and school preparedness to distance learning education tailored from the "Distance Education Models and Best Practices" (Academy Administration Practice, 2011) and (4) challenges in distance learning education during the enhanced community quarantine in the Philippines tailored from the study of Musingafi, Mapuranga, Chiwanza and Zebron, (2015). The questionnaire was face and content validated by the experts in distance learning education and experts in health to ensure that items about COVID-19 are scientifically correct and relevant. The final evaluation was done by five more experts, which consisted of a high school teacher, two university Professors, and two Department of Education Public School District Supervisor (PSDS). The suggestions and corrections were incorporated in the final format of the instrument before disseminating it online. Furthermore, the survey tool got 8.9 Cronbach's alpha in the initial reliability test conducted two weeks before the study commenced.

\subsection{Data Analysis}

All data collected and tabulated from the Google form within the first two weeks of ECQ was considered part of the study. Descriptive statistics was used to 
describe the demographic profile, teachers' awareness about COVID 19, distance learning education readiness, and its challenges. Non- parametric tests were also used to draw inferences on the data collected. The Mann Whitney $U$ test and Kruskal Wallis test were utilized to compare the means of teachers' demographic profile to awareness of COVID-19 and readiness to distance learning education. Moreover, Spearman Rho was calculated to correlate the teachers' awareness of COVID-19 and readiness to distance learning education as well as their demographic profile to teachers' awareness of COVID-19 and readiness to distance learning education. Table 1 shows Spearman's Rho correlation interpretation adapted from Dancey and Reidy (2004).

Table 1. Interpretation table of Spearman rank-order correlation coefficients

\begin{tabular}{cc}
\hline Spearman $\mathbf{p}$ & Correlation \\
\hline 0.70 & Very strong relationship \\
$0.40-0.69$ & Strong relationship \\
$0.30-0.39$ & Moderate relationship \\
$0.20-0.29$ & Weak relationship \\
$0.01-0.19$ & No or negligible relationship
\end{tabular}

*This descriptor applies to both positive and negative relationships.

\section{Results}

\subsection{Teacher' demographic profile}

Around 2300, teachers all over the country participated in this study. As it is shown in Table 2, teachers from Luzon $(43 \%)$ dominated the population size of the study followed by Mindanao (29\%) and the least in number is Visayas (28\%); likewise, dominated by teachers who are teaching in urban areas and teachers who are teaching in the high school level. In terms of the gender of the participants, most of the teachers were females and mostly with teaching experience of six (6) to ten (10) years. More responses from female-teacher respondents than male-teacher respondents were expected because, according to Esplada (2010), DepEd records showed that 86 percent of the total population of teachers in the Philippines are female.

In terms of the teaching specialization, the participants were divided according to strands currently used by the Senior High School program in the Philippines. Most of the participants were teaching subjects under the Science Technology Engineering and Mathematics (STEM) strand, whereas the Technical Vocational Livelihood strand majors were the least in terms of numbers. A few teachers from private and international schools $(0.09 \%)$ also participated in the study. 
Table 2. Teachers' Demographic Profile

\begin{tabular}{|c|c|c|c|}
\hline & & Frequency & $\begin{array}{c}\text { Percentage } \\
(\%)\end{array}$ \\
\hline \multirow[t]{2}{*}{ Teachers' Schools Location } & Urban & 2104 & 91 \\
\hline & Rural & 196 & 9 \\
\hline \multirow[t]{2}{*}{ School Type } & Public & 2297 & 99 \\
\hline & Private & 21 & 1 \\
\hline \multirow[t]{3}{*}{ Teachers' Geographic Location } & Luzon & 995 & 43 \\
\hline & Visayas & 650 & 28 \\
\hline & Mindanao & 656 & 29 \\
\hline \multirow[t]{2}{*}{ Teachers' Gender } & Male & 383 & 17 \\
\hline & Female & 1917 & 83 \\
\hline \multirow[t]{5}{*}{ Teachers' Teaching Experience } & $\begin{array}{c}\text { Below } 5 \\
\text { years }\end{array}$ & 299 & 13 \\
\hline & $6-10$ years & 1370 & 60 \\
\hline & $11-15$ years & 496 & 21 \\
\hline & $16-20$ years & 86 & 4 \\
\hline & $\begin{array}{l}21 \text { years } \\
\text { and above }\end{array}$ & 49 & 2 \\
\hline \multirow[t]{4}{*}{ Teachers' Specialization } & STEM & 1134 & 49 \\
\hline & HUMMS & 588 & 26 \\
\hline & $\mathrm{ABM}$ & 439 & 19 \\
\hline & $\begin{array}{l}\text { TECH } \\
\text { VOC }\end{array}$ & 141 & 6 \\
\hline \multirow[t]{3}{*}{ Level of Education Taught } & Elementary & 698 & 60 \\
\hline & $\begin{array}{l}\text { High } \\
\text { School }\end{array}$ & 1443 & 63 \\
\hline & College & 159 & 7 \\
\hline
\end{tabular}

\subsection{Teachers' COVID-19 awareness and readiness to distance learning} education

Table 3 shows the percentage of teachers' awareness of the COVID-19 pandemic, which consisted of a five-statement survey. Most of the respondents acknowledged that they were aware of COVID-19 being a global pandemic that can easily transmit in populated areas like schools. The fact that news and information about the COVID-19 pandemic can be easily accessed through various media such as the internet, TV, radio, and social media; however, 28 out of 2300 teachers are not aware that Luzon is under ECQ. 
It can be gleaned from these results that almost all of the teachers who accomplished the survey are aware of the COVID-19 pandemic and its effect on the studies of their students. This information is vital as this survey was conducted during the initial stages of pandemic spread and lockdown where a lot of chaos and confusion was rampant not only in the Philippines but all over the World.

Table 3. Percentage of teachers' and schools' readiness to distance education due to COVID-19 Pandemic

\begin{tabular}{llccc}
\hline & Teachers' Awareness to COVID-19 & YES (\%) & NO (\%) & Maybe (\%) \\
\hline 1 & $\begin{array}{l}\text { Aware that COVID-19 is a global } \\
\text { pandemic. } \\
\text { Aware that the government declared } \\
\text { the Enhanced Community } \\
\text { Quarantine in Luzon. }\end{array}$ & $2299(99)$ & $1(0)$ & $0(0)$ \\
3 & $\begin{array}{l}\text { Aware that the government declared } \\
\text { the Enhanced Community } \\
\text { Quarantine in Luzon. }\end{array}$ & $2256(99)$ & $0(0)$ & $16(0)$ \\
$4 \begin{array}{l}\text { Aware of the Dos and Don'ts during } \\
\text { the Enhanced Community } \\
\text { Quarantine. }\end{array}$ & $2299(99)$ & $0(0)$ & $1(0)$ \\
5 & $\begin{array}{l}\text { Aware of the importance of social } \\
\text { distancing to prevent the spread of } \\
\text { COVID-19. }\end{array}$ & $2289(99)$ & $5(0)$ & $1(0)$ \\
\hline
\end{tabular}

Table 3 shows the percentage of teachers' and schools' readiness to distance education due to the COVID-19 pandemic. This part of the survey was composed of two parcels, the first parcel was the teachers' readiness to distance learning education. In contrast, the second parcel was the schools' readiness to distance learning education. Almost 99\% of respondents answered "YES" when asked if they were ready to conduct distance learning education during difficult times; however, only $69 \%$ confirmed in affirmative when asked if they were prepared to use the printed module as a tool for distance learning. $58 \%$ of the respondents were ready to use online modules or learning materials available on the internet, such as Youtube, Ted Talk and Khan Academy and learning management systems like Edmodo, Canvas, Google Classroom, and Zoom as means of online or distance learning education. To the question, if they are well-equipped and ready for distance learning, the respondents' response was not equally divided, with $51 \%$ of respondents giving their answers in affirmative. These results imply that the lack of facilities, equipment, and capacity building to distance learning education hinder the teachers in offering distance learning education.

\subsection{Readiness of Educational Institutions and Schools}

The respondents' schools were also surveyed by asking their opinions on the readiness of their respective institutions. $62 \%$ of the respondents answered YES when asked if their school has an information dissemination system to communicate with the parents and the learners during the COVID-19 outbreak (Table 4). However, in terms of the capacity building on distance learning education offered by the school to teachers $(40 \%)$ and if it has a designated 
workforce for the COVID-19 (45\%), only a few answered "YES." Moreover, 51\% of the respondents replied "YES" when asked if their school has provided the regulations and policies on distance learning to protect students' identity and data privacy. Still, only 37\% answered "YES" when asked if their school has provided supplementary materials for distance learning such as subscriptions to online libraries and the procurement of online learning management systems.

Based on the responses regarding their schools' readiness on distance learning education, though most of the respondents are teaching in urban areas, there are still several basic education schools that are not equipped with the facilities, amenities and training to distance learning education during difficult times.

Since the education system is going to avoid face to face interaction, the school/institutions will have to play a vital role in this journey of transition since they are the ones who provide training and workshops for the teachers to be equipped with the skills and knowledge in distance learning education. Furthermore, the schools/insitutions are the ones who plan, implement and evaluate a school activity or program like distance learning education to ensure their success.

Table 4. Percentage of teachers' and schools' readiness to distance education due to COVID-19 Pandemic

\begin{tabular}{|c|c|c|c|c|}
\hline & $\begin{array}{l}\text { Teacher's Readiness to Distance Learning } \\
\text { Education Due to COVID-19 }\end{array}$ & YES (\%) & NO (\%) & Maybe (\%) \\
\hline 1. & $\begin{array}{l}\text { Ready to conduct distance learning } \\
\text { education to my students in times of COVID- } \\
19\end{array}$ & 2299 (99) & $0(0)$ & $0(0)$ \\
\hline 2. & $\begin{array}{l}\text { Ready to use the printed module as a tool for } \\
\text { learning at home. }\end{array}$ & 1589 (69) & $238(10)$ & $473(21)$ \\
\hline 3. & $\begin{array}{l}\text { Ready to use online modules or learning } \\
\text { materials available on the internet such as } \\
\text { Youtube, Ted Talk, and Khan Academy. }\end{array}$ & $1331(58)$ & $526(23)$ & 443 (19) \\
\hline 4. & $\begin{array}{l}\text { Ready to utilize learning management } \\
\text { systems like Edmodo, Canvas, Google } \\
\text { Classroom, or Zoom as a means of online or } \\
\text { distance learning education. }\end{array}$ & $1330(58)$ & $525(23)$ & 444 (19) \\
\hline \multirow[t]{2}{*}{5.} & $\begin{array}{l}\text { Well-equipped and ready for distance } \\
\text { learning since I attended a training or } \\
\text { workshop on distance learning education } \\
\text { management. }\end{array}$ & $1170(51)$ & $526(24)$ & $568(25)$ \\
\hline & $\begin{array}{l}\text { Schools' Preparedness to Distance Learning } \\
\text { Education Due to COVID-19 }\end{array}$ & Yes (\%) & No (\%) & Maybe (\%) \\
\hline 6. & $\begin{array}{l}\text { The school has a system of information } \\
\text { dissemination to communicate with the } \\
\text { parents and the learners during the CoVid-19 } \\
\text { outbreak. }\end{array}$ & $1415(62)$ & 397 (17) & $488(21)$ \\
\hline 7. & $\begin{array}{l}\text { The school has provided capacity building } \\
\text { on distance learning education management } \\
\text { for teachers. }\end{array}$ & $917(40)$ & $744(32)$ & $639(28)$ \\
\hline 8. & $\begin{array}{l}\text { The school has a designated workforce for } \\
\text { the COVID-19. }\end{array}$ & $1026(45)$ & $656(30)$ & $568(25)$ \\
\hline
\end{tabular}




\begin{tabular}{lllll}
\hline 9. & $\begin{array}{l}\text { The school has provided the regulations and } \\
\text { policies on the use of distance learning to } \\
\text { protect student's identity and data privacy. }\end{array}$ & $1165(51)$ & $556(24)$ & $579(25)$ \\
10 & $\begin{array}{l}\text { The school has provided supplementary } \\
\text { materials for distance learning such as } \\
\text { subscriptions to online libraries, } \\
\text { procurement of online learning management } \\
\text { systems. }\end{array}$ & $851(37)$ & $748(33)$ & $701(30)$ \\
\end{tabular}

\subsection{Teachers' Challenges in Distance Learning education}

The mean $(\mathrm{M})$ and standard deviation (SD) were the bases of determining the teachers' perceptions of the challenges in delivering distance learning education (Table 5). The SD pertains to how the data were spread out. A high standard deviation means that the data looks spread out. The values are interpreted as $0.0-$ 1.0 = Strongly Disagree; 1.1-2.0= Disagree; 2.1-3.0= Agree; and 3.1-4.1=Strongly Agree.

The problems encountered by teachers in offering distance learning education are the challenges on knowledge and skills required in delivering distance learning education classes $(M=2.71 ; S D=0.88)$, problems on establishing communication with students $(M=2.75 ; S D=0.89)$, challenges on having stable internet access intended for distance learning education $(\mathrm{M}=2.69 ; \mathrm{SD}=0.99)$, challenges on the use of phones, laptops, and tablets or any devices for distance learning education $(\mathrm{M}=2.67 ; \mathrm{SD}=0.88)$, and challenges on the use of any Learning Management System $(\mathrm{M}=2.71 ; \mathrm{SD}=0.86)$.

In addition, the respondents also agreed that they encountered challenges in the use of social media, emails and other platforms of distance learning education ( $\mathrm{M}=2.66$; $\mathrm{SD}=0.90)$, giving instruction and responding to queries through email and messages $(M=2.68 ; S D=0.90)$, encouraging participation and utilization of features in online classes $(\mathrm{M}=2.72 ; \mathrm{SD}=0.89)$, time management in the conduct of classes, monitoring of responses, availability of students and other online classes issues $(\mathrm{M}=2.73 ; \mathrm{SD}=0.89)$ and the sudden shift from face to face to online classes $(\mathrm{M}=2.69 ; \mathrm{SD}=0.88)$.

Lastly, respondents also agreed that they faced problems managing the stress caused by community quarantine at home and in between online classes demands $(\mathrm{M}=2.71 ; \mathrm{SD}=87)$. As well as beating the deadlines and requirements set by the school administrators $(\mathrm{M}=2.60 ; \mathrm{SD}=0.88)$, establishing a network of communication among stakeholders such as parents for support at home (M= $2.74 ; 0.85)$, checking and evaluating students output from the email of an online learning Management System $(2.67 ; 0.88)$ and building a positive environment in online classes through emotional support among students aside from contentbased teaching and learning $(\mathrm{M}=2.70 ; \mathrm{SD}=0.88)$.

Such problems would be easily solved if adequately addressed. The school should carefully plan how they will offer a distance learning education to students. Also, continued monitoring and evaluation of the program would significantly help enhance the system of distance learning education. 
Table 5. Perceived challenges in distance learning education

\begin{tabular}{|c|c|c|c|c|}
\hline & ITEM & $\begin{array}{l}\text { MEAN } \\
(\mathrm{N}=2300)\end{array}$ & SD & $\begin{array}{c}\text { Verbal } \\
\text { Interpretation }\end{array}$ \\
\hline 1 & $\begin{array}{l}\text { Challenges on Knowledge and skills } \\
\text { required in delivering distance learning } \\
\text { education classes }\end{array}$ & 2.71 & 0.88 & AGREE \\
\hline 2 & $\begin{array}{l}\text { Challenges on establishing communication } \\
\text { with my students }\end{array}$ & 2.75 & 0.89 & AGREE \\
\hline 3 & $\begin{array}{l}\text { Challenges on having stable internet access } \\
\text { intended for distance learning education }\end{array}$ & 2.69 & 0.99 & AGREE \\
\hline 4 & $\begin{array}{l}\text { Challenges on the use of phones, laptops, } \\
\text { and tablets or any devices for distance } \\
\text { learning education }\end{array}$ & 2.67 & 0.88 & AGREE \\
\hline 5 & $\begin{array}{l}\text { Challenges on the use of any Learning } \\
\text { Management System (LMS) }\end{array}$ & 2.71 & 0.86 & AGREE \\
\hline 6 & $\begin{array}{l}\text { Challenges on Use of social media, e-mails, } \\
\text { and other platforms of distance learning } \\
\text { education. }\end{array}$ & 2.66 & 0.90 & AGREE \\
\hline 7 & $\begin{array}{l}\text { Challenges on Giving instruction and } \\
\text { responding to queries through e-mail and } \\
\text { messages. }\end{array}$ & 2.68 & 0.90 & AGREE \\
\hline 8 & $\begin{array}{l}\text { Challenges on Encouraging participation } \\
\text { and utilization of features in online classes }\end{array}$ & 2.72 & 0.89 & AGREE \\
\hline 9 & $\begin{array}{l}\text { Challenges on Time management in the } \\
\text { conduct of classes, monitoring of } \\
\text { responses, availability of students, and } \\
\text { other online classes issues. }\end{array}$ & 2.73 & 0.89 & AGREE \\
\hline 10 & $\begin{array}{l}\text { Challenges on the sudden shift from face } \\
\text { to face to online classes. }\end{array}$ & 2.69 & 0.88 & AGREE \\
\hline 11 & $\begin{array}{l}\text { Challenges on Managing the stress caused } \\
\text { by community quarantine at home and in } \\
\text { between online classes demands. }\end{array}$ & 2.71 & 0.87 & AGREE \\
\hline 12 & $\begin{array}{l}\text { Challenges on Beating the deadlines and } \\
\text { requirements set by the school } \\
\text { administrators. }\end{array}$ & 2.60 & 0.88 & AGREE \\
\hline 13 & $\begin{array}{l}\text { Challenges on Establishing a network of } \\
\text { communication among stakeholders such } \\
\text { as parents for support at home. }\end{array}$ & 2.74 & 0.85 & AGREE \\
\hline 14 & $\begin{array}{l}\text { Challenges on Checking and evaluating } \\
\text { students' output from the e-mail of an } \\
\text { online Learning Management System. }\end{array}$ & 2.67 & 0.88 & AGREE \\
\hline 15 & $\begin{array}{l}\text { Challenges on Building a positive } \\
\text { environment through online classes } \\
\text { through emotional support among my } \\
\text { students aside from content-based teaching } \\
\text { and learning. }\end{array}$ & 2.70 & 0.88 & AGREE \\
\hline
\end{tabular}




\subsection{Testing differences and relationships between teachers' demographic profile and teachers' awareness of COVID-19 and readiness in distance learning education}

Inferential statistics was used in testing relationships and differences among variables. Since the data drawn from this study are not normally distributed and have unequal variances, non-parametric tests were used in drawing inferences. Such as the Spearman rho correlation for testing relationships between variables, Mann Whitney $U$ tests for testing difference for two independent variables and Kruskal Wallis test for testing difference for three or more independent variables.

The correlation between teacher's demographic profiles and awareness to COVID-19 shows no relationship at all (Table 6). This result entails that teachers' awareness of the COVID-19 pandemic has nothing to do with their demographic profile since the pandemic facts are learned mostly through the media. However, in terms of the correlation between teachers' demographic profiles and readiness to distance Learning education, the length of teaching experience and specialization are found to be very strongly correlated ("Very Strong Relationship") to readiness to distance learning education. In contrast, the teachers' geographic location is moderately correlated ("Strong Relationship") to readiness to distance learning education.

Table 6. Correlation between teachers' demographic profile and awareness of COVID-19 pandemic and Readiness to distance learning education

\begin{tabular}{|c|c|c|c|c|c|}
\hline Cate & zory & $\begin{array}{c}\text { Teachers' } \\
\text { Awareness } \\
\text { of COVID- } \\
19\end{array}$ & Interpretation & $\begin{array}{l}\text { Teachers' } \\
\text { Readiness } \\
\text { to Distance } \\
\text { Learning } \\
\text { Education }\end{array}$ & Interpretation \\
\hline $\begin{array}{l}\text { Length of } \\
\text { teaching } \\
\text { experience }\end{array}$ & $\begin{array}{c}\text { Correlation } \\
\text { Coefficient } \\
\text { Sig. (2-tailed) }\end{array}$ & $\begin{array}{r}-.0 .39 \\
.057\end{array}$ & $\begin{array}{l}\text { Moderate } \\
\text { Relationship }\end{array}$ & $\begin{array}{c}0.70^{* *} \\
.001\end{array}$ & $\begin{array}{l}\text { Very Strong } \\
\text { Relationship }\end{array}$ \\
\hline $\begin{array}{l}\text { School Type } \\
\text { (Private/ } \\
\text { Public) }\end{array}$ & $\begin{array}{l}\text { Correlation } \\
\text { Coefficient } \\
\text { Sig. (2-tailed) }\end{array}$ & $\begin{array}{l}-.029 \\
.158\end{array}$ & $\begin{array}{c}\text { No } \\
\text { Relationship }\end{array}$ & $\begin{array}{l}-.021 \\
.316\end{array}$ & $\begin{array}{c}\text { No } \\
\text { Relationship }\end{array}$ \\
\hline $\begin{array}{l}\text { School location } \\
\text { (Urban/rural) }\end{array}$ & $\begin{array}{l}\text { Correlation } \\
\text { Coefficient } \\
\text { Sig. (2-tailed) }\end{array}$ & $\begin{array}{l}.004 \\
.865\end{array}$ & $\begin{array}{c}\text { No } \\
\text { Relationship }\end{array}$ & $\begin{array}{l}-.004 \\
.849\end{array}$ & $\begin{array}{c}\text { No } \\
\text { Relationship }\end{array}$ \\
\hline $\begin{array}{l}\text { Teachers' } \\
\text { Specialization }\end{array}$ & $\begin{array}{l}\text { Correlation } \\
\text { Coefficient } \\
\text { Sig. (2-tailed) }\end{array}$ & $\begin{array}{l}-.039 \\
.056\end{array}$ & $\begin{array}{c}\text { No } \\
\text { Relationship }\end{array}$ & $\begin{array}{l}0.72^{* *} \\
.001\end{array}$ & $\begin{array}{l}\text { Very Strong } \\
\text { Relationship }\end{array}$ \\
\hline $\begin{array}{l}\text { Teachers' } \\
\text { Geographical } \\
\text { location }\end{array}$ & $\begin{array}{c}\text { Correlation } \\
\text { Coefficient } \\
\text { Sig. (2-tailed) }\end{array}$ & -.029 & $\begin{array}{c}\text { No } \\
\text { Relationship }\end{array}$ & $0.62^{* *}$ & $\begin{array}{c}\text { Strong } \\
\text { Relationship }\end{array}$ \\
\hline
\end{tabular}


Tables 7 and 8 show the difference between respondents' demographic profile and awareness of the COVID-19 pandemic and the readiness to distance learning education. Among the respondents' demographic profiles, only their gender $(U=358415 ; p=0.008)$ has a significant difference with their awareness of COVID19. Likewise, teachers' gender $(U=346415 ; p=0.006)$, length of teaching experience $(X 2(4)=19.093 ; p=0.001)$ and geographic location $(X 2(2)=10.937 ; p=0.004)$ have significant differences with their readiness to distance learning education. Since most of the respondents are female teachers, it can be gleaned that female teachers are more aware of the facts about COVID-19 and its effects on their students' studies than male teachers.

Table 7. Mann-Whitney $U$ test between teachers' demographic profiles and awareness of COVID-19 and readiness to distance education

\begin{tabular}{llcc}
\hline Category & $\begin{array}{c}\text { Teachers' } \\
\text { Awareness of } \\
\text { COVID-19 }\end{array}$ & $\begin{array}{c}\text { Teachers' Readiness to } \\
\text { Distance Learning } \\
\text { Education }\end{array}$ \\
\hline $\begin{array}{l}\text { School Type } \\
\text { (Private/ Public) }\end{array}$ & Mann-Whitney U & 202368.000 & 196414.500 \\
& Z & -1.411 & -1.004 \\
Gender & Mannp. Sig. (2-tailed) & .158 & .316 \\
& Z & 358415.000 & 346415.000 \\
School location & Asymp. Sig. (2-tailed) & .008 & -2.528 \\
(Urban/rural) & Mann-Whitney U & 202368.000 & .006 \\
& Z & 1.411 & 196414.500 \\
& Asymp. Sig. (2-tailed) & .158 & -1.004 \\
& & & .316 \\
\hline
\end{tabular}

Table 8. Kruskal Wallis test between teachers' demographic profiles and awareness of COVID-19 and readiness to distance education

\begin{tabular}{llcc}
\hline \multicolumn{1}{c}{ Category } & Chi-Square & $\begin{array}{c}\text { Teachers' } \\
\text { Awareness of } \\
\text { COVID-19 }\end{array}$ & $\begin{array}{c}\text { Teachers' Readiness to } \\
\text { Distance Learning } \\
\text { Education }\end{array}$ \\
\hline $\begin{array}{l}\text { Length of teaching } \\
\text { experience }\end{array}$ & 6.035 & 19.093 \\
& Af & 4 & 4 \\
Teachers' & Chi-Square & 3.688 & .001 \\
Specialization & df & 4 & 3.688 \\
Teachers' & Asymp. Sig. & .450 & 4 \\
Geographic location & Chi-Square & 1.837 & .450 \\
& df & 2 & 10.973 \\
Teachers' level of & Asymp. Sig. & .399 & 2 \\
education handled & Chi-Square & 2.282 & .004 \\
& df & 2 & 8.061 \\
& Asymp. Sig. & .320 & 2 \\
& & & .068 \\
\hline
\end{tabular}




\section{Discussions}

This study aimed to gather data on the awareness of teachers in the Philippines on COVID-19 pandemic and the challenges they have faced during the sudden shift from face to face classes to distance learning education. Teachers were aware that the Philippines had declared ECQ due to COVID-19 pandemic as well as the rules and regulations during the ECQ like the social distancing measures, which were strictly observed and implemented in schools and institutions based on observational modeling to alleviate school's closure (Viner et al., 2020). In the case of China, the "One Stop Learning" was launched during the COVID-19 outbreak which aimed to develop an approach or program about the updates on COVID19, public health issues, online education announcement, teachers preparation, academic research hub and logistic operation to pursue undisrupted learning (Huang, Liu, Tlili, Yang \& Wang, 2020).

Based on the response made by the respondents on the readiness of their schools to distance learning education, and though most of the respondents are in the urban areas, there are still more basic education schools that are not equipped with the facility and training to distance learning education during difficult times. To keep abreast of distance learning education trends, the teachers should be equipped with the knowledge and skills in distance learning education (Rhini, 2018). The creation of audio-visual materials are viewed as very effective in increasing academic performance (Tang \& Intai, 2017; and Lapada, 2017). Institutions can do this by providing sets of training and workshops; likewise, schools should invest more in the facilities and equipment for distance learning. It is continuously evolving; it is a must to be updated to cater to a changing learning environment (Bozkurt, 2019).

Today, the DepEd Philippines is slowly providing computers, tablets, and smart boards to schools which are center of excellence or central schools. These innovations are needed for distance learning education and for embracing the trend in education 4.0, which promotes the use of the E-instruction system, enabling learners' autotomy achievement and implementing a task-based and performance-based on a specific learning goal (Chen \& Huang, 2018; and Hussin, 2018). With regard to communicating with students, teachers may plan a strategy on how to keep in touch with students like the use of online platforms; however, due to unstable internet connection in rural areas, providing print-based modules will also be useful. For elementary teachers, it is possible to communicate with their pupils through their parents. However, for students in high schools, teachers may use online platforms since they are tech-savvy using technologies such as email and social media (Uslo, 2018). However, building a positive attitude in doing activities through distance learning should also be taught to students to work at their own pace. The students' activities and homework should also be interactive and suited to the learners to catch their interest (Mascreen, Pai, \& Pai, 2012; and Harackiewicz, Smith \& Priniski, 2016).

The length of teaching experience affects the readiness to distance learning education since teachers who have taught for several years have more experience dealing with difficult times like the pandemics or natural calamities (Kini \& 
Podolsky, 2016). However, the teachers with more number of years of teaching experience are by default in the older age group and hence are relatively less tech savy. This group of teachers particulary need more assitance in using the online tools to deliver their lessons. However, teachers who have served for a long time have had the opportunity to attend seminar workshops needed in offering distance learning education. Teachers' specialization may also affect the teachers' readiness to distance learning education because some specialties under the Technical Vocational Livelihood (TVL) strand have better experiences in using technological materials used in teaching (Yunus et al., 2017). Moreover, the teachers' geographical location may also affect distance education (Rivza \& Bogdan, 2017). Luzon has the highest number of urbanized cities with stable internet connections and accessible roads compared with Mindanao and the Visayas; this is one of the reasons why teachers from urban areas are more ready to distance learning education than teachers from rural areas.

Furthermore, female respondents are more ready to offer distance learning education to their students. These results agree with other studies where it was reported that as per the international technology education standards in higher institutions, female respondents significantly differ in terms of technology literacy, which is a requirement for offering distance learning education (Alwraikat, 2017). Further, teachers with more years of teaching experience were also found to be more ready for distance learning education; moreover, the College teachers were the best in terms of their readiness to offer distance learning education compared to the basic education teachers. Teachers in college and university have more advanced facilities and equipment for teaching and learning. This is commendable as it is already known that support from stakeholders, accessibility, and culture-based learning objectives are critical factors in institutional leadership and management among higher educational institutions that are adopting e-learning (Singh et al., 2017).

For these challenging times, teachers have to re-think of an intervention to deliver their lessons rather than face to face encounters. The school plays a vital role in this journey since they are the ones who provide training and workshops for the teachers to be equipped with the skills and knowledge in distance learning education (Darling-Hammond et al., 2019). Distance learning education could build access for learners in college education. However, distance learning education might be hard to execute in the laboratory classes, yet they can boost technology utilization (Mahlangu, 2018). And lastly, the schools must know how to plan, implement and evaluate a school activity or program like distance learning education to ensure its success.

\section{Conclusion}

This pursuit is intended to accumulate information on teachers' awareness in the Philippines on COVID-19 pandemic and the difficulties they have experienced during the abrupt shift from face to face classes to distance learning education. Almost all the teachers who participated in this study were highly aware of the COVID-19 pandemic and how it is going to impact the education of their students. The information is essential as the survey for this study was done during the 
pandemic's initial period, which points to the overall higher levels of awareness among the teaching community. The teachers expressed their readiness to switch to distance learning education; however, they felt hampered due to lack of facilities, equipment, and capacity building to distance learning education. The correlation between teacher's demographic profiles and awareness to COVID-19 showed no relationship at all. Nevertheless, the length of teaching experience and specialization were very strongly correlated to readiness to distance learning education while the teachers' geographic location was strongly correlated to readiness to distance learning education. Furthermore, the teachers' gender had a significant difference in their awareness of COVID-19. In contrast, teachers' gender, length of teaching experience, and geographic location had significant differences with their readiness to distance learning education. Overall, the teaching community is mentally prepared to adapt to new and innovative ways of imparting knowledge, provided their institutions well support them.

\section{Recommendations}

The awareness of educators on the risk posed by the COVID-19 pandemic and the implementation of the enhanced community quarantine dictates a call for action for an alternative mode of learning. The adaptation of various online education institutions in the first two weeks of ECQ is a good indicator of good practices in the teaching and learning process.

To prevent the second wave of the pandemic, it is recommended by this study that the schools should opt for distance learning for the coming school year along with providing teachers' capability building for distance learning education. Likewise, investing in the facilities and equipment needed for distance learning is an excellent idea to enhance the institution's capability in delivering distance learning to the students.

It is further recommended to restructure the course syllabus that is simple and attainable in the learner's level of limited capacity restricted by social distancing. Specific measures such as adopting remote (Dixon \& Kirmes, 2020) and flexible learning (Huang, Liu, Tlili, Yang \& Wang, 2020) be considered for those who lack access to the internet connection and other resources. The feasibility of the delivery of printed materials through the local courier should also be taken into account. It will be beneficial to harness various media to feature academic lessons in audio, printed, and visual like TV and radio with schedule and monitoring based on conducive learning time. In terms of on-the-job training and practical laboratory works, contextualization of learning design and output can be considered. It will also be an advantage if there will be parent line communication or a portal (Miguel \& Abulon, 2016) for the interest of completion, progress, and mental health monitoring at home. Furthermore, continued monitoring and evaluation of the distance learning education program would be a great help to enhance the system of delivering education.

\section{Acknowledgement}

The authors would like to extend their deepest gratitude to all the teachers in the Philippines who participated in the survey for this study. 


\section{References}

Academy Administration Practice. (2011). Distance Education Models and Best Practices. DC: Washington, Imperial Valley College. Retrieved from https://www.imperial.edu/ivc/files/Distance_Education_Models_and_Best_Pr actices.pdf

Akarawang, C., Kidrakran, P., \& Nuangchalerm, P. (2015). Enhancing ICT Competency for Teachers in the Thailand Basic Education System. International Education Studies, 8(6). https://doi.org/10.5539/ies.v8n6p1

Alwraikat, M. (2017). A glimpse at international technology education standards in higher education institutions, International Journal of Instructional Technology Distance Learning, 8(5). https://doi.org/2014.10

Bozkurt, A. (2019). From Distance Education to Open and Distance Learning. (January), 252273. https://doi.org/10.4018/978-1-5225-8431-5.ch016

Chen, J. F., \& Huang, H. F. (2018). An empirical study on the factors influencing the webbased teaching effect. Eurasia Journal of Mathematics, Science and Technology Education, 14(5), 1635-1643. https:/ / doi.org/10.29333/EJMSTE/85035

Dancey C., \& Reidy J. (2004). Statistics without maths for psychology: using SPSS for windows. London, England: Prentice-Hall.

Darling-Hammond, L., Flook, L., Cook-Harvey, C., Barron, B., \& Osher, D. (2020). Implications for educational practice of the science of learning and development. $\begin{array}{llll}\text { Applied Developmental } & \text { Science, } & \text { 24(2), }\end{array}$ https://doi.org/10.1080/10888691.2018.1537791

Department of Education. (2020a). Creation of a Task Force for the Management of Department of Education Response to Novel Coronavirus Acute Respiratory Disease (2019-nCoV $A R D)$. Retrieved from: https://www.deped.gov.ph/category/issuances/depedmemoranda/

Department of Education. (2020b). Towards A Sustainable and Working DepEd Commons Part II: A Framework. Retrieved from: https://commons.deped.gov.ph/depedcommons-framework.pdf

Dill E., Fischer K., McMurtrie B., \& Supiano B. (2020). As Coronavirus Spreads, the Decision to Move Classes Online Is the First Step. What Comes Next? The Chronicle of Higher Education. Retrieved from: https://www.chronicle.com/article/As-Coronavirus Spreads-the $/ 248200$

Dixon, B. M., \& Kirmes, J. L. (2020). Remote Learning Recommendations During Covid-19 Emergency, 62. Retrieved from: https://www.isbe.net/Pages/covid19.aspx

Esguerra, D. (2020. April 3). Nearly 20K avail of TESDA free online courses amid Luzon lockdown. Inquirer.net. Retrieved from: https:// newsinfo.inquirer.net/1253335/nearly-20k-avail-of-tesda-free-onlinecourses-amid-luzon-lockdown

Esplada, J. (2010). Male teachers in the Phillipines. Philippine Daily Inquirer Online. Retrieved from: http://www.menteach.org/news/male_teachers_in_the_phillipines\#: :text= Women\%2DpoweredDepEd\%20records\%20furnished \%20to,over\%20the\%20cou ntry \%20were \% 20women

Fedina, N. V., Burmykina, I. V., Zvezda, L. M., Pikalova, O. S., Skudnev, D. M., \& Voronin, I. V. (2017). Study of educators' and parents' readiness to implement distance learning technologies in preschool education in Russia. Eurasia Journal of Mathematics, Science and Technology Education, 13(12), 8415-8428. https://doi.org/10.12973/ejmste/80802

Guo, Y., Cao, Q., Hong, Z., Tan, Y., Chen, S., Jin, H., Tan, K., Wang, D., Yan, Y. (2020). The origin, transmission and clinical therapies on coronavirus disease 2019 (COVID- 
19) outbreak - an update on the status. Military Med Res, 7(11). https://doi.org/10.1186/s40779-020-00240-0

Harackiewicz, J. M., Smith, J. L., \& Priniski, S. J. (2016). Interest Matters: The Importance of Promoting Interest in Education. Policy insights from the behavioral and brain sciences, 3(2), 220-227. https:// doi.org/10.1177/2372732216655542

Huang, R. H., Liu, D. J., Tlili, A., Yang, J. F., \& Wang, H. H. (2020). Handbook on facilitating flexible learning during educational disruption: The Chinese experience in maintaining undisrupted learning in COVID-19 Outbreak. Smart Learning Institute of Beijing Normal University UNESCO, 1-54. Retrieved from: https://iite.unesco.org/news/handbook-on-facilitating-flexible-learningduring-educational-disruption/

Hussin, A. A. (2018). Education 4.0 Made Simple: Ideas For Teaching. International Journal of Education \& Literacy Studies. http:// dx.doi.org/10.7575/aiac.ijels.v.6n.3p.92

Kini, T., \& Podolsky, A. (2016). Does Teaching Experience Increase Teacher Effectiveness? A Review of the Research. Palo Alto: Learning Policy Institute. Retrieved from: https://learningpolicyinstitute.org/sites/default/files/product-

files/Teaching_Experience_Report_June_2016.pdf

Lapada, A. A. (2017). Audio-visual aided instruction in science among high school students in the Philippines. International Journal of Education and Research, 5(7), 139-156.

Lu, H., Stratton C. W., \& Tang Y. W. (2020). Outbreak of pneumonia of unknown etiology in Wuhan, China: the mystery and the miracle. Journal of Medical Virology, 92(4), 401-402. https://doi.org/10.1002/jmv.25678

Mahlangu, V. P. (2018). The Good, the Bad, and the Ugly of Distance Learning in Higher Education. IntechOpen. http://dx.doi.org/10.5772/intechopen.75702

Malipot, M. H. (2020). DepEd expands online learning platforms for out-of-school learners. Retrieved April 1, 2020, https://news.mb.com.ph/2020/04/01/deped-expandsonline-learning-platform-for-out-of-school-learners/

Martin, F., Budhrani, K., \& Wang, C. (2019). Examining faculty perception of their readiness to teach online. Online Learning Journal, 23(3), 97-119. https://doi.org/10.24059/olj.v23i3.1555

Mascreen, C., Pai, P. Y., \& Pai, R. Y. (2012). Identifying Factors for the Enrollment of Students towards Distance Education for Master's Course: A Student's Perspective. International Journal for Digital Society, 3(3), 689-694. https://doi.org/10.20533/ijds.2040.2570.2012.0084

Miguel, F. F., \& Abulon, E. L. R. (2016). Teacher-Parent Collaborative Efforts in Facilitating Students' Homework. The Normal Lights- Journal on Teachers Education Special Issue 2016, 18-32.

Movkebayeva, Z., Derijan, I., Khamitova, D., \& Akhmetova, A. (2018). Teacher Readiness For Distance Education Of Disabled Students. International Journal - Knowledge In Practice, 28, 1011-1014. https://doi.org/10.35120/kij28031011Z

Musingafi, M. C. C., Mapuranga, B., Chiwanza, K., \& Zebron, S. (2015). Challenges for Open and Distance learning (ODL) Students: Experiences from Students of the Zimbabwe Open University. Journal of Education and Practice, 6(18), 59-67.

Nassaji, H. (2016). Qualitative and descriptive research: Data type versus data analysis Qualitative and descriptive research: Data type versus data analysis. Language Teaching Research, 19(2) 129-132. https:/ / doi.org/10.1177/1362168815572747

Ozturk, D. S., Ozturk, F., \& Ozen, R. (2018). The relationship between prospective teachers' readiness and satisfaction about web-based distance education. Turkish Online $\begin{array}{llll}\text { Journal of Distance Education, 19(1), 147-162. } & \text {. }\end{array}$ https://doi.org/10.17718/tojde.382791 
Phan, T. T. N., \& Dang, L. T. T. (2017). Teacher Readiness for Online Teaching: A Critical Review. International Journal Open Distance E-Learn. IJODeL, 3(1), 1-16.

Quimba, F. M. A., Dumaua-Cabauatan, M., Calizo, S. C., \& Pacio, L. C. (2018). E-Education in the Philippines: The Case of Technical Education and Skills Development Authority Online Program. Discussion Papers No. 2018-08, 1-45. Retrieved from: https://pidswebs.pids.gov.ph/CDN/PUBLICATIONS/pidsdps1808_rev.pdf

Rivza, B., \& Bogdan, R. (2017). Evaluation of Readiness for Distance Education of Students in European Universities Evaluation of Readiness for Distance Education of Students in European Universities. BRAIN: Broad Research in Artificial Intelligence and Neuroscience, 8(1). Retrieved from: https://www.edusoft.ro/brain/index.php/brain/article/view/673

Rhini, F. (2018). Teaching Practice in Distance Education Context. SHS Web of Conferences, 42, 1-7. https://doi.org/10.1051/shsconf/20184200099

Singh, G., Naz, R., \& Narayan, J. (2017). Investigating critical factors for adoption of elearning in the South Pacific region. Instructional Technology and. International Journal Of Instructional Technology Distance Learning, 8(5). https:/ / doi.org/2014.10

Tang, D. K. H., \& Intai, R. (2017). Effectiveness of audio-visual aids in teaching lower secondary science in a rural secondary school. Asia Pacific Journal of Educators and Education, 32, 91-106. https://doi.org/10.21315/apjee2017.32.7

Uslu, Ö. (2018). Factors Associated with Technology Integration to Improve Instructional Abilities: A Path Model. Australian Journal of Teacher Education, 43(4). http:/ /dx.doi.org/10.14221/ajte.2018v43n4.3

Ventayin, R. J. (2018). Teachers' Readiness in Online Teaching Environment: A Case of Department of Education Teachers. Journal of Education, Management and Social Sciences, 2(1). Retrieved from www.psurj.org/jemss

Viner, R. M., Russell, S. J., Croker, H., Packer, J., Ward, J., Stansfield, C., ... Booy, R. (2020). School closure and management practices during coronavirus outbreaks, including COVID-19: a rapid systematic review. The Lancet Child and Adolescent Health, 4(5), 397-404. https://doi.org/10.1016/S2352-4642(20)30095-X

World Bank. (2020a). Remote Learning, Distance Education and Online Learning During the COVID19 Pandemic. eLearning World Bank. https://doi.org/10.1596/33499

World Bank. (2020b). How countries are using Edtech (including online learning, radio, and television, texting) to support access to remote learning during the COVID-19 pandemic. Retrieved April 8. 2020,_https://www.worldbank.org/en/topic/edutech/brief/

WHO. (March,2020). Coronavirus disease 2019 Report (COVID-19), Situation Report - 59. Retrieved from: https://www.who.int/docs/defaultsource/coronaviruse/situation-reports/20200319-sitrep-59-covid19.pdf?sfvrsn=c3dcdef9_2

Yunus, F. A., Tun, U., Onn, H., Alias, M., Tun, U., Onn, H., ... Onn, H. (2017). Vocational pedagogy among technical vocational education and training teachers. Proceedings of IEEE International Conference on Industrial Engineering and Engineering Management (IEEM), (pp. 150-154). Singapore. https://doi.org/10.1109/IEEM.2017.8289869 